\title{
Optimization of the process of obtaining $\mathrm{RE}_{2} \mathrm{O}_{3}$ from xenotime using statistical design
}

\section{(Otimização do processo de obtenção de $\mathrm{RE}_{2} \mathrm{O}_{3}$ a partir da xenotima usando planejamento estatístico)}

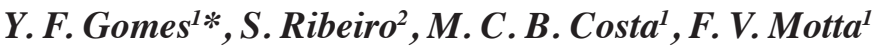 \\ ${ }^{1}$ Departamento de Engenharia de Materiais, Universidade Federal do Rio Grande do Norte, \\ Av. Sen. Salgado Filho 3000, Natal, RN, Brasil 59072-970 \\ ${ }^{2}$ DEMAR, EEL, USP, Polo Urbo Industrial, Gleba AI6, Lorena, SP, Brasil 12600-970 \\ *yfeliciano@gmail.com
}

\begin{abstract}
The study of the production of the mixed rare earth oxide $\left(\mathrm{RE}_{2} \mathrm{O}_{3}\right)$ from xenotime via hydrometallurgy was performed to evaluate the significance of the effects of three factors including the melting temperature (A), the ratio of NaOH/xenotime (B), and time (C) for the first stage of alkaline fusion by using full $2^{3}$ factorial design. Also, seven factors were studied including liquid/solid ratio (LS), inert $\left(\mathrm{I}_{1}\right)$, excess $\mathrm{HNO}_{3}(\mathrm{EA})$, temperature (TL), inert $\left(\mathrm{I}_{2}\right)$, time $(\mathrm{HL})$, and inert $\left(\mathrm{I}_{3}\right)$ for the second and third steps, which were the oxalic acid leaching and precipitation, using Plackett-Burman design (PBD). Optimizing factors for significance were performed using plots of interactions, analysis of variance (ANOVA), Pareto charts, surface charts, analysis of Student's t-test and F test. A regression model was suggested and satisfactorily adjusted for the experimental data of the process of alkaline fusion, revealing an elevated coefficient of determination $\left(\mathrm{R}^{2}=0.92\right)$ to a $\mathrm{F}_{\text {calculated }}$ value well above the $\mathrm{F}_{\text {tabulated }}$ value, at a $95 \%$ confidence level. The $\mathrm{RE}_{2} \mathrm{O}_{3}$ was characterized by chemical analysis, X-ray diffraction, scanning electron microscopy, and specific surface area. This process resulted in a material with identical physical and chemical properties to the isolated compounds of rare earths and can be used as an alternative sintering additive in advanced ceramics, and indicated that the cost of final production of $\mathrm{RE}_{2} \mathrm{O}_{3}$ can be lower compared to commercial $\mathrm{Y}_{2} \mathrm{O}_{3}$.
\end{abstract}

Keywords: xenotime, alkaline fusion, acid leaching, precipitation, statistical design.

Resumo

$O$ estudo da produção da mistura de óxido de terra rara $\left(\mathrm{RE}_{2} \mathrm{O}_{3}\right)$ de xenotima via hidrometalurgia foi realizado para avaliar o significado dos efeitos de três fatores: temperatura de fusão $(A)$, proporção de NaOH/xenotima $(B)$ e tempo $(C)$ para a primeira fase de estudo de fusão alcalina usando um planejamento fatorial completo $2^{3}$. Além disso, foram estudados sete fatores, incluindo a proporção líquido/sólido $(L S)$, inerte $\left(I_{1}\right)$, excesso de $H N O_{3}(E A)$, temperatura $(T L)$, inerte $\left(I_{2}\right)$, tempo $(H L)$ e inerte $\left(I_{3}\right)$ para a segunda e terceira etapas, que foram lixiviação do ácido oxálico e precipitação, usando o planejamento experimental PlackettBurman (PBD). Fatores de otimização para os efeitos de significância foram realizados utilizando parcelas de interações, análise de variância (ANOVA), gráficos de Pareto, gráficos de superfície, análise do teste t de Student e o teste F. Um modelo de regressão foi sugerido e satisfatoriamente ajustado para os dados experimentais do processo de fusão alcalina, revelando um coeficiente elevado de determinação $\left(R^{2}=0,92\right)$ a um valor $F$ calculado bem acima do valor F tabulado, a um nível de confiança de $95 \%$. $\mathrm{O} \mathrm{RE} \mathrm{O}_{3}$ foi caracterizado por análise química, difração de raios $X$, microscopia eletrônica de varredura e área de superfície específica. Este processo resultou em um material com propriedades físicas e químicas idênticas aos compostos isolados de terras raras e pode ser usado como um aditivo de sinterização alternativo em cerâmicas avançadas e indicou que o custo de produção final de $\mathrm{RE}_{2} \mathrm{O}_{3}$ pode ser menor em comparação com $\mathrm{Y}_{2} \mathrm{O}_{3}$ comercial.

Palavras-chave: xenotima, fusão alcalina, precipitação, planejamento estatístico.

\section{INTRODUCTION}

Rare earth (RE) has its use in glass, metal, nuclear technology, ceramics, and are widely used as highperformance catalysts, as well as for high efficient production of permanent magnets and phosphors. The electronic structure of the elements of RE confer special properties such as magnetism, luminescence and laser applications, among others [1-3]. The rare earth elements are ranked, usually into two subgroups: a light fraction or subset of cerium (ceric lands), comprising the elements of atomic numbers 57-63 (La to Eu) and a heavy fraction or subgroup yttrium (yttric lands) which contain the elements of atomic numbers 64 to 71 (Gd to Lu), besides yttrium itself. Despite its low atomic weight, yttrium is categorized with the heavy rare earths because of its mode of occurrence, ionic radius and other properties which are closer to the elements of the heavy fraction $[4,5]$.

The main sources of rare earths are the classic ores/ minerals such as monazite, xenotime and bastnasite. 
Xenotime, a phosphate, and some RE-carrying clays are the main sources of supply of rare earth elements from the heavy fraction $[6,7]$. Xenotime is a phosphate mineral with rare earth crystal structure (space group $14_{1} /$ amd, $Z=4$ ), which typically consists of $25 \% \mathrm{Y}_{2} \mathrm{O}_{3}$ and other heavy elements, but may have as much as $60 \% \mathrm{Y}_{2} \mathrm{O}_{3}$ and $40 \%$ other rare earth oxides [8,9]. Brazil has identified RE resources of the order of 30 million tons, with the largest reserves and the highest concentration of rare earths being found in lateritic and silexitos soils associated with carbonatite complexes. Here, the term identified resources is used with the same meaning assigned to identified resources by the U.S. Geological Survey: resources whose characteristics, location, content and quantity are known or estimated from specific geological evidence, including economic, marginally economic and subeconomic components [3]. The literature reports that with phosphate matrix, the minerals xenotime and monazite have rare earth extracted by acid or basic lixiviation/leaching [10, 11]. Experimental studies using alkaline leaching and alkaline fusion to recover rare earth oxide indicated a yield of about $95 \%$ of rare earths extracted from xenotime [10]. Using an acid route, monazite and xenotime are digested in sulfuric acid and finally leached in hydrochloric acid producing a mixture of rare earth elements [2]. The effects of various parameters involving the hydrometallurgical process has the influence of many factors that can be studied quantitatively, where the importance of each variable must be determined [4, 12-14].

In this study, the optimization of the production process of the mixed rare earth oxide $\left(\mathrm{RE}_{2} \mathrm{O}_{3}\right)$ from xenotime via hydrometallurgy was divided into three stages; the first was the process of alkaline fusion based on full $2^{3}$ factorial design. The second step was the process of leaching, and the third stage was the process of oxalic precipitation, where both phases were based on Plackett-Burman design (PBD). The full $2^{3}$ factorial design is an important and simple statistical tool. The observation of the effects of the variables of the melting temperature (A), the ratio of $\mathrm{NaOH} /$ xenotime (B), time (C), and their interactions is of utmost importance to understand the process of acid leaching [15]. The PBD allows estimating all $\mathrm{k}=\mathrm{N}-1$ main effects, where $\mathrm{N}$ represents the number of experiments with minimum variance, proving to be efficient in the evaluation of a large number of variables and identifying the most significant $[16,17]$. In PBD design, seven factors were evaluated: the liquid/solid ratio (LS), inert $\left(I_{1}\right)$, excess $\mathrm{HNO}_{3}(\mathrm{EA})$, temperature $(\mathrm{TL})$, inert $\left(\mathrm{I}_{2}\right)$, time (HL), and inert $\left(\mathrm{I}_{3}\right)$ for the second and third steps, which were the oxalic acid leaching and precipitation, respectively. The advantage of this method is to reduce the number of experiments that investigate interactions between factors chosen from the RSM yields of reactions for each experiment [18]. In both plans response surface methodology (RSM) was used, an optimization technique that has been used with great success in the modeling of various industrial products $[15,18]$.

\section{MATERIALS AND METHODS}

For the optimization, the methodology for the production of $\mathrm{RE}_{2} \mathrm{O}_{3}$ was performed in three steps: the first step of the alkaline fusion process, based on the full $2^{3}$ factorial design; the second and third stages of oxalic acid leaching and precipitation, respectively, were performed using the Plackett-Burman design (PBD).

Alkaline fusion: xenotime from Pitinga Mine, located in Presidente Figueiredo (AM-Brazil), and $98 \% \mathrm{NaOH}$ in flakes (Sinc) were stoichiometrically weighed according to the experimental variables and levels used in the construction of the full $2^{3}$ factorial design, which observed the effects of varying the fusion temperature (A), the ratio of $\mathrm{NaOH} /$ xenotime (B), and time (C). The materials were mixed in a double cone mixer for $1 \mathrm{~h}$ and the mixtures obtained were heated in an electric furnace for times and temperatures pre-determined in the full $2^{3}$ factorial design, with the objective of transforming xenotime, which is an insoluble rare earth phosphate - insoluble in nitric acid. The product of the alkaline fusion was fragmented and crushed in a ball mill. Then, an aqueous leaching was performed to separate the insoluble product $\mathrm{Na}_{3}\left(\mathrm{RO}_{3}\right)$ from sodium phosphate $\left(\mathrm{Na}_{3} \mathrm{PO}_{4}\right)$, soluble in water. This step was performed in a vacuum filtration system. The product was dried at $100{ }^{\circ} \mathrm{C}$ and sieved with/until a particle size of 40 mesh.

Acid leaching: the product from the previous step, consisting of a salt of rare earth sodium was reacted in a glass reactor by reflux with nitric acid $\left(\mathrm{HNO}_{3} 66 \mathrm{Be}\right)$. The system showed a mixture consisting of a liquid phase (liquor) containing dissolved rare earth and a solid phase containing insoluble impurities. In the acid leaching step, the experimental design used was the statistical PlackettBurman approach (PBD) that investigated the interactions with the seven factors of liquid/solid ratio (LS), inert $\left(\mathrm{I}_{1}\right)$, excess $\mathrm{HNO}_{3}(\mathrm{EA})$, temperature (TL), inert $\left(\mathrm{I}_{2}\right)$, time (HL), and inert $\left(\mathrm{I}_{3}\right)$.

Oxalic precipitation: in this third step, we used the liquor/ solution diluted with water to $5 \mathrm{~g} / \mathrm{L}$ at $\mathrm{pH}=1$, obtained by acid leaching conditions previously laid down by the same Plackett-Burman design (PBD) used in the second stage. A solution of oxalic acid $(\mathrm{C}=80 \mathrm{~g} / \mathrm{L})$ was added to the liquor in constant agitation at $200 \mathrm{rpm}$ at room temperature to avoid loss of rare earth. Then, the oxalate formed was separated from the reaction medium by sedimentation followed by filtration. After this step, the product was subjected to washing with water to remove residual soluble salts. The rare earth oxalate was calcined at $800{ }^{\circ} \mathrm{C}$ for $4 \mathrm{~h}$.

Experimental schedules: the full $2^{3}$ factorial design was used to evaluate the effects of three factors $(\mathrm{k})$ of the alkaline fusion step. The total number of experiments required for this experimental design method is given by $2^{k}=2^{3}=8$. The observation of the effects of varying the fusion temperature (A), the ratio of $\mathrm{NaOH} /$ xenotime (B), processing time (C), and their respective values are shown in Table I. The purpose of using the Plackett-Burman design (PBD) is to evaluate the effects of selected factors and identify the most influential 
Table I - Factors and levels analyzed during the stage of alkaline fusion.

[Tabela I - Fatores e níveis analisados durante o estágio de fusão alcalina.]

\begin{tabular}{cccc}
\hline Factor & Notation & Level $(-)$ & Level $(+)$ \\
\hline Fusion temperature & $\mathrm{A}$ & $600{ }^{\circ} \mathrm{C}$ & $700{ }^{\circ} \mathrm{C}$ \\
Ratio NaOH:xenotime & $\mathrm{B}$ & $1.0 \mathrm{w} / \mathrm{w}$ & $1.3 \mathrm{w} / \mathrm{w}$ \\
Time & $\mathrm{C}$ & $180 \mathrm{~min}$ & $240 \mathrm{~min}$ \\
\hline
\end{tabular}

Table II - Variables in the leaching acid and their respective levels.

[Tabela II - Variáveis da lixiviação ácida e seus respectivos níveis.]

\begin{tabular}{cccc}
\hline Variable & Notation & Level $(+)$ & Level (-) \\
\hline Liquid/solid ratio & $\mathrm{LS}$ & $10 / 1 \mathrm{~kg}$ & $5 / 1$ \\
Inert & $\mathrm{I}_{1}$ & - & - \\
Excess $\mathrm{HNO}_{3}$ & $\mathrm{EA}$ & $20 \%$ & $10 \%$ \\
Temperature & $\mathrm{TL}$ & $100{ }^{\circ} \mathrm{C}$ & $90{ }^{\circ} \mathrm{C}$ \\
Inert & $\mathrm{I}_{2}$ & - & - \\
Time & $\mathrm{HL}$ & $20 \mathrm{~min}$ & $10 \mathrm{~min}$ \\
Inert & $\mathrm{I}_{3}$ & - & - \\
\hline
\end{tabular}

in the process of the second and third steps, which is the oxalic acid leaching and precipitation, respectively. PBD investigated interactions with seven factors which are liquid/ solid ratio (LS), inert $\left(\mathrm{I}_{1}\right)$, excess $\mathrm{HNO}_{3}(\mathrm{EA})$, temperature (TL), inert $\left(\mathrm{I}_{2}\right)$, length (HL) and inert $\left(\mathrm{I}_{3}\right)$, presented in Table II which shows variables (real and inert) and their respective higher (+) and lower (-) levels studied.

Response methodology (RSM): for this study the statistical schedules were performed using software (Statistic Ver 7.0). The response values used included the yield of the reactions in the process steps, and the reactions were performed according to the values shown in Tables I and II. Upon statistical analysis, it was possible to obtain a mathematical model that represents the process for the studied levels. For a $2^{3}$ factorial design, the mathematical equation that describes this system can be represented by the linear polynomial equation [19]; this model (Eq. A) is a simpler model with fewer factors for a well-established, systematic errors are absent, and normalized residuals resulted from experimental errors which exhibit a normal distribution according to a widely accepted statistical convention:

$\hat{\mathrm{y}}\left(\mathrm{X}_{1}, \mathrm{X}_{2} \mathrm{X}_{3}\right)=\mathrm{b}_{0}+\mathrm{b}_{1} \mathrm{X}_{1}+\mathrm{b}_{2} \mathrm{X}_{2}+\mathrm{b}_{3} \mathrm{X}_{3}+\mathrm{b}_{12} \mathrm{X}_{1} \mathrm{X}_{2}+$ $b_{13} X_{1} X_{3}+b_{23} X_{2} X_{3}+b_{123} X_{1} X_{2} X_{3}+\varepsilon\left(X_{1}, X_{2}, X_{3}\right)$

Characterization: the chemical composition of $\mathrm{RE}_{2} \mathrm{O}_{3}$ was determined by optical emission spectrometry with inductively coupled plasma (ICP-OES Varian Vista MPX). The crystal structure was characterized by X-ray diffraction (XRD) using Rich Seiferst equipment (Debeyeflex 1001) with $\mathrm{CuK} \alpha$ radiation, operating at $25 \mathrm{~mA} / 30 \mathrm{kV}$. The specific surface area was determined by $\mathrm{N}_{2}$ adsorption
(BET method), Quantachrome, Nova 1000 equipment. Morphological characterization was performed by LEO scanning electron microscope (SEM, 1450-VP).

\section{RESULTS AND DISCUSSION}

For the evaluation of the effects studied in the first stage of alkaline fusion, Table III presents a matrix of $2^{3}$ factorial design with the factors fusion temperature (A), ratio of $\mathrm{NaOH} /$ xenotime (B), time $(\mathrm{C})$, and responses obtained in the yield of the reactions. The yield of alkaline fusion is the transformation of xenotime to a rare earth compound $\mathrm{Na}_{3} \mathrm{RO}_{3}$ insoluble in water and $\mathrm{Na}_{3} \mathrm{PO}_{4}$, according to:

$\mathrm{RPO}_{4(\mathrm{~S})}+6 \mathrm{NaOH}_{(\mathrm{S})} \rightarrow \mathrm{Na}_{3}\left(\mathrm{RO}_{3}\right)_{(\mathrm{S})}+\mathrm{Na}_{3} \mathrm{PO}_{4(\mathrm{~S})}+3 \mathrm{H}_{2} \mathrm{O}_{(\mathrm{V})}$

Table III - Response values, $\mathrm{R}_{1}$ and $\mathrm{R}_{2}$, obtained in alkaline fusion, using full $2^{3}$ factorial design, conducted in replicated. [Tabela III - Valores de resposta, $R_{1}$ e $R_{2}$, obtidos na fusão alcalina, usando planejamento fatorial completo $2^{3}$.]

\begin{tabular}{cccccc}
\hline Run number & $\mathrm{A}$ & $\mathrm{B}$ & $\mathrm{C}$ & $\mathrm{R}_{1}(\%)$ & $\mathrm{R}_{2}(\%)$ \\
\hline 1 & - & - & - & 67.87 & 67.27 \\
2 & + & - & - & 69.73 & 74.47 \\
3 & - & + & - & 69.80 & 70.20 \\
4 & + & + & - & 88.93 & 89.80 \\
5 & - & - & + & 67.47 & 71.13 \\
6 & + & - & + & 77.13 & 80.20 \\
7 & - & + & + & 83.73 & 84.53 \\
8 & + & + & + & 92.93 & 96.20 \\
\hline
\end{tabular}

The results obtained in planning indicate an increase in the average yield of $67.27 \%$ to $96.20 \%$, when all variables are simultaneously level -1 to +1 . Therefore, within this range of operation, the alkaline fusion gave a better yield, or an efficient transformation of xenotime in $\mathrm{Na}_{3} \mathrm{RE}_{3}$ and $\mathrm{Na}_{3} \mathrm{PO}_{4}$. Table IV presents the estimated effects, standard errors, and Student t-test for yield response of alkaline fusion, according to the $2^{3}$ factorial design. Through statistical analysis, it was found that the main effects of factors A, B and C, and the effect of interaction between A and B were statistically significant at a $95 \%$ confidence level. The positive effect of the interaction $\mathrm{A} * \mathrm{~B}$ means that the yield of fusion is favored with a concomitant increase of temperature and relative $\mathrm{NaOH}$ :xenotime ratio, i.e. in this case a synergistic effect of interaction occurs between the variables B and A. After examination of the significant regression on the yield of the reaction factors, a linear model was fitted to experimental data:

$$
\text { Yield }(\%)=78.21+5.46 \mathrm{~A}+6.30 \mathrm{~B}+3.45 \mathrm{C}+1.99 \mathrm{AB}
$$

where $\mathrm{A}, \mathrm{B}$ and $\mathrm{C}$ are the coded values for temperature, $\mathrm{NaOH}$ :xenotime relation, and fusion time, respectively.

The statistical significance of the empirical model of the 
Table IV - Estimates of the effects, standard errors and Student $\mathrm{t}$-test for yield response of alkaline fusion, using the full factorial design $2^{3}$.

[Tabela IV - Erros padrão e teste t de Student para a resposta do rendimento da fusão alcalina, utilizando o planejamento fatorial completo $2^{3}$.]

\begin{tabular}{cccc}
\hline Factor & Estimate (\%) & $\begin{array}{c}\text { Standard } \\
\text { error }\end{array}$ & $\mathrm{t}_{\text {calc }}$ \\
\hline Average & $78.21^{*}$ & \pm 0.73 & 107.43 \\
Temperature (A) & $10.92^{*}$ & \pm 1.46 & 7.50 \\
NaOH:xenotime (B) & $12.61^{*}$ & \pm 1.46 & 8.66 \\
Time (C) & $6.91^{*}$ & \pm 1.46 & 4.74 \\
AB & $3.98^{*}$ & \pm 1.46 & 2.73 \\
AC & -1.02 & \pm 1.46 & 0.70 \\
BC & 2.76 & \pm 1.46 & 1.89 \\
\hline
\end{tabular}

first order was evaluated by $\mathrm{F}$ test (ANOVA), which revealed a high coefficient of determination $\left(\mathrm{R}^{2}=0.92\right)$ and also $\mathrm{F}_{\text {calculated }}$ value well above the $\mathrm{F}_{\text {tabulated }}$, to a $95 \%$ confidence level (Table $\mathrm{V})$. For the regression to be statistically significant, the value of $F_{\text {calculated }}$, or the $\mathrm{MQ}_{\mathrm{R}} / \mathrm{MQ}_{\mathrm{r}}$ ratio should be at least 4 times the value of $\mathrm{F}_{\text {tabuleted }}[16,21]$. In this case, $\mathrm{F}_{\text {calculated }}$ is approximately 10 times greater than the $\mathrm{F}_{\text {tabulated }}$, which shows that the model described by Eq. C is highly significant. Fig. 1 shows a graph of

Table V - Analysis of variance for the adjustment of the first order to yield data on the alkaline fusion step model.

[Tabela V-Análise de variância para o ajuste a fim de se obter dados sobre o modelo de fusão alcalina.]

\begin{tabular}{cccccc}
\hline $\begin{array}{c}\text { Source } \\
\text { variation }\end{array}$ & SQ & Gl & MQ & $\mathrm{F}_{\text {calculated }}$ & $\mathrm{F}_{\text {tabulated }}$ \\
\hline Regression & 1367.01 & 4 & 341.75 & 33.87 & $3.36^{*}$ \\
Waste & 110.95 & 11 & 10.09 & & \\
Total & 1477.96 & 15 & & & \\
\hline
\end{tabular}

Notes: $F_{\text {set }}$ values at $95 \%$ confidence; \% explained variation $\left(R^{2}\right): S Q_{R} / S Q_{T}=0.92$.

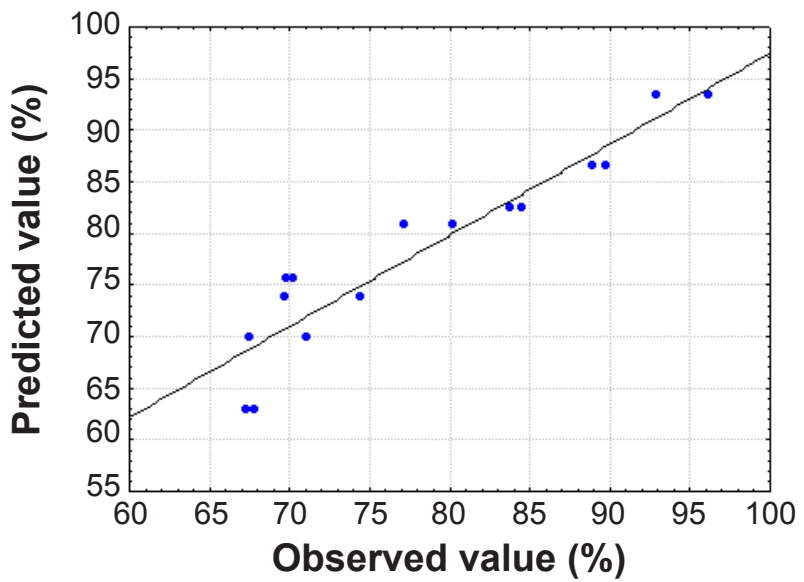

Figure 1: Graph of the values calculated by the model on the basis of experimental values obtained.

[Figura 1: Gráfico dos valores calculados pelo modelo com base nos valores obtidos experimentalmente.]

the values calculated by the model on the basis of experimental values obtained. It can be seen that the predicted values are well adjusted to the experimental data, confirming again that the model is highly significant.

The RSMs determined by the linear model equation, which describes the values of yield of alkaline fusion depending on the manipulated variables in the process are shown in Fig. 2 , where we have each variable in their relationships with their statistical significance for this study. The maximum yield predicted by the model is obtained at higher levels of temperature and the relation $\mathrm{NaOH}$ :xenotime (Fig. 2a). All main effects of the independent variables are positive, presenting positive correlation with the variable yield response so that as the manipulated variables increased, the yield of the reaction also increased (Figs. 2b and 2c).

The alkaline material from the fusion process at optimized conditions (all variables in the upper level), after washing with water, was reacted with nitric acid under different experimental conditions, according to:
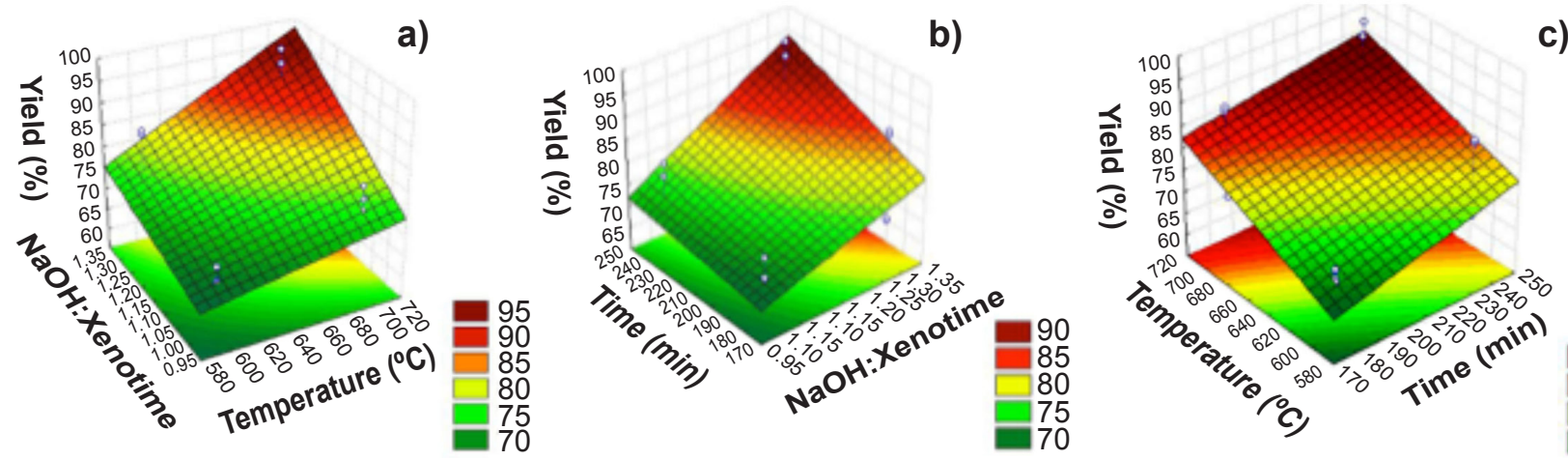

Figure 2: Response surfaces and contour plots showing the effects of the independent variables on positive correlation with the variable yield response: (a) $\mathrm{NaOH}$ :xenotime and temperature; (b) time and $\mathrm{NaOH}$ :xenotime; and (c) temperature and time.

[Figura 2: Superfícies de resposta e efeitos mostrados através das variáveis independentes com relação positiva à variável de resposta: (a) $\mathrm{NaOH}$ :xenotima e temperatura; (b) tempo e NaOH:xenotima; e (c) temperatura e tempo.] 
Table VI - Plackett-Burman design for the study of 4 variables with 8 trials during the stage of acid leaching.

[Tabela VI - Plackett-Burman para o estudo de 4 variáveis com 8 ensaios durante a fase de lixiviação ácida.]

\begin{tabular}{ccccccccc}
\hline Run n $^{\circ}$ & LS & $\mathrm{I}_{1}$ & EA & TL & $\mathrm{I}_{2}$ & $\mathrm{HL}$ & $\mathrm{I}_{3}$ & Yield $(\%)$ \\
\hline 1 & + & + & + & - & + & - & - & 74.72 \\
2 & + & + & - & + & - & - & + & 86.45 \\
3 & + & - & + & - & - & + & + & 82.89 \\
4 & - & + & - & - & + & + & + & 84.38 \\
5 & + & - & - & + & + & + & - & 86.56 \\
6 & - & - & + & + & + & - & + & 83.81 \\
7 & - & + & + & + & - & + & - & 86.55 \\
8 & - & - & - & - & - & - & - & 87.24 \\
\hline
\end{tabular}
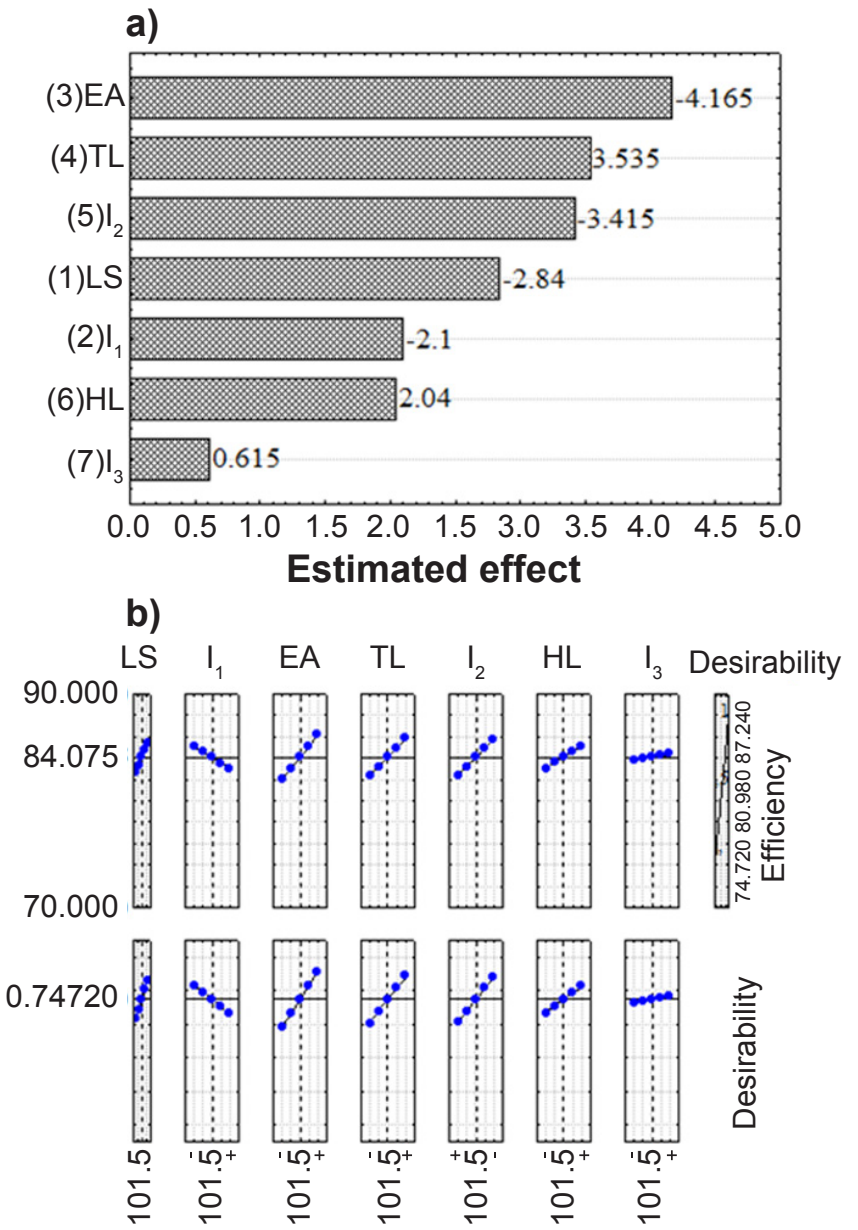

Figure 3: Estimated effects of studied variables (a), and results of desirability analysis (b) showing that the excess $\mathrm{HNO}_{3}$ (EA) and temperature (TL) had significant positive effects with the yield of the acid leaching step.

[Figura 3: Efeitos estimados das variáveis estudadas (a) e resultados da análise de conveniência (b) mostrando que o excesso de $\mathrm{HNO}_{3}$ (EA) e temperatura (TL) tiveram efeitos positivos e significativos com o rendimento da lixiviação ácida.]

For the acid leaching stage, the PBD results are expressed in terms of output, i.e. the maximum conversion of yttrium and rare earth salts in solution, given in Table VI. This is Plackett-Burman design for the study of 4 variables with 8 trials during the stage of acid leaching, in case $\mathrm{I}_{1}$ and $\mathrm{I}_{2}$. Fig. 3 shows the significance of the effects after statistical analysis of the design data by PBD. Through analysis of the Pareto chart, Fig. 3a showed that, among the estimated impact of the 7 factors assessed, the excess $\mathrm{HNO}_{3}$ (EA) had the greatest importance in the process, followed by temperature (TL). Fig. 3b confirms through desirability analysis that the excess $\mathrm{HNO}_{3}(\mathrm{EA})$ and temperature (TL) were the two factors that had significant positive correlations with the yield of the acid leaching step.

The statistical significance of each effect can be determined by Student's t-test. For the design of PBD, the number of dummy variables is the number of degrees of freedom for the entry in the table of $\mathrm{t}$, for a given confidence interval $[15,20]$. In this work, a confidence level of $95 \%$ with the tabulated value of $t$ equal to 3.18 was used. Comparing the values of $t$ given in Table VII, it can be verified that at this level all effects showed a $t_{\text {calc }}$ value lower than $t_{\text {tabul }}$. This indicated a lower significance of effects on the yield of the acid leaching.

Table VII - Estimates of the effects, Student's t test and $\mathrm{p}$-value for the factors used in the leaching step (PBD).

[Tabela VII - Estimativas dos efeitos, teste $t$ de Student $e$ valor de p para os fatores utilizados na etapa de lixiviação (PBD).]

\begin{tabular}{ccccc}
\hline Variable & Notation & $\begin{array}{c}\text { Estimate } \\
(\%)\end{array}$ & $\mathrm{t}_{\text {calc }}$ & $\mathrm{p}$-value \\
\hline $\begin{array}{c}\text { Liquid/solid } \\
\text { ratio }\end{array}$ & LS & -2.840 & -1.21 & 0.31 \\
$\begin{array}{c}\text { Excess } \mathrm{HNO}_{3} \\
\text { Temperature }\end{array}$ & EA & -4.165 & 1.78 & 0.17 \\
Time & HL & 3.535 & 1.51 & 0.23 \\
\hline
\end{tabular}

Lastly, the oxalic precipitation was achieved in solution produced in the leaching step (experiment 8), employing lower levels of the studied factors. The concentration of precipitant solution used for conversion of the oxalates to oxides of rare earths was $80 \mathrm{~g} / \mathrm{mL}$, thus obtaining a yield of $98.25 \%$. Oxalic acid has great selectivity, allowing for the attainment of rare earth oxalates which are insoluble in the reaction medium used [21-23]. According to the statistical design, we obtained oxalate by calcination from XRD pattern in Fig. 4a for the mixed rare earth oxide, in the precipitation step at $800{ }^{\circ} \mathrm{C}$ for $2 \mathrm{~h}$. The decomposition of the oxalate group occurred between $340-410{ }^{\circ} \mathrm{C}$ as reported in the literature [24]. Fig $4 \mathrm{~b}$ shows the XRD pattern of a physical mixture of the main constituent oxides observed in the chemical analysis performed on $\mathrm{RE}_{2} \mathrm{O}_{3}$ by ICP-OES (Table VIII). It can be seen in the mechanical mixture spectrum that the diffraction peaks of the individual oxides are identified. The behavior of the mixed rare earth oxide observed in the XRD pattern suggested that the constituents 


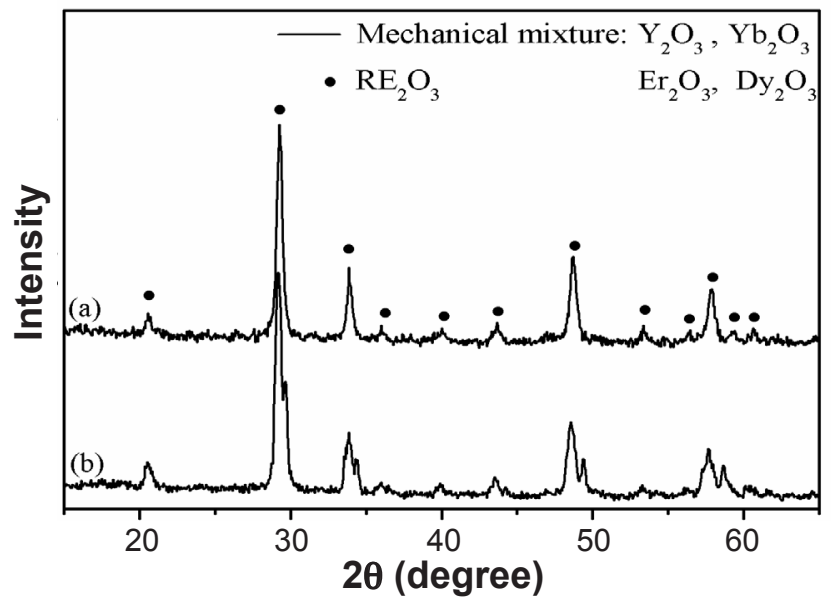

Figure 4: X-ray diffraction patterns of: (a) mixed rare earth oxide after calcination at $800{ }^{\circ} \mathrm{C}$ for $2 \mathrm{~h}$; and (b) physical mixture of the main constituent oxides.

[Figura 4: Difratogramas de raios $X$ de: (a) mistura de óxidos de terra rara calcinada a $800{ }^{\circ} \mathrm{C}$ por $2 \mathrm{~h}$; e (b) mistura dos pós de óxidos constituintes.]

Table VIII - Chemical analysis performed on $\mathrm{RE}_{2} \mathrm{O}_{3}$ by ICPOES.

[Tabela VIII - A análise química realizada em $\mathrm{RE}_{2} \mathrm{O}_{3}$ por ICP-OES.]

\begin{tabular}{cccc}
\hline Oxide & $\%$ mass & Oxide & $\%$ mass \\
\hline $\mathrm{Y}_{2} \mathrm{O}_{3}$ & 44.1 & $\mathrm{Sm}_{2} \mathrm{O}_{3}$ & 0.45 \\
$\mathrm{Yb}_{2} \mathrm{O}_{3}$ & 19.2 & $\mathrm{ZrO}_{2}$ & 0.16 \\
$\mathrm{Er}_{2} \mathrm{O}_{3}$ & 13.6 & $\mathrm{Nd}_{2} \mathrm{O}_{3}$ & 0.15 \\
$\mathrm{Dy}_{2} \mathrm{O}_{3}$ & 10.5 & $\mathrm{CeO}_{2}$ & 0.09 \\
$\mathrm{Ho}_{2} \mathrm{O}_{3}$ & 3.16 & $\mathrm{CaO}$ & 0.06 \\
$\mathrm{Tm}_{2} \mathrm{O}_{3}$ & 2.88 & $\mathrm{La}_{2} \mathrm{O}_{3}$ & 0.04 \\
$\mathrm{Lu}_{2} \mathrm{O}_{3}$ & 2.55 & $\mathrm{Eu}_{2} \mathrm{O}_{3}$ & 0.02 \\
$\mathrm{Gd}_{2} \mathrm{O}_{3}$ & 1.26 & $\mathrm{TiO}_{2}$ & 0.01 \\
$\mathrm{~Tb}_{4} \mathrm{O}_{7}$ & 0.88 & & \\
\hline
\end{tabular}

of the same metals, as oxides, form a solid solution of yttrium matrix due to the similarity of the rare earths (atomic radius, ionic radius, electronegativity and valence). The peaks were slightly displaced with respect to the rare earth oxides with the highest concentration found in xenotime [22-26].

Chemical analysis by atomic emission spectroscopy by induced plasma (Table VIII) done in mixed rare earth oxide showed the highest percentages of oxides: $\mathrm{Y}_{2} \mathrm{O}_{3}(44.1$ $\mathrm{wt} \%)$ and $\mathrm{Yb}_{2} \mathrm{O}_{3}(19.2 \mathrm{wt} \%)$. The great variability of the composition of natural xenotime is verified by literature $[8,22-28]$, showing that there are different compositions of xenotime with heavy rare earths, like $\mathrm{Y}, \mathrm{U}$ and Th. Specifically, xenotime grains usually obtained from granite around the world are characterized by compositions comprising 70 to $80 \mathrm{~mol} \% \mathrm{Y}\left(\mathrm{PO}_{4}\right)+16$ to $25 \mathrm{~mol} \%$ heavy in rare earth phosphates [8].

The result presented for the analysis of specific surface area via BET was $6.48 \mathrm{~g} / \mathrm{cm}^{3}$. This value showed that the powder obtained had characteristics suitable for direct application without the need for grinding, however for synthesis of advanced ceramics, it needs to be mixed and ground with other parts, thereby losing its initial characteristics. The bimodal particle size distribution of $\mathrm{RE}_{2} \mathrm{O}_{3}$, with a wide range of distribution, varied from 0.40 to $80 \mu \mathrm{m}$. This wide distribution facilitates the compaction of the powder, which could make mixtures of ceramics to be sintered via liquid phase. Fig. 5 shows SEM micrographs in which it was observed that the particles form evenly-rounded clusters. The irregular particles provide more contact points, which facilitates the compaction of the material and thereafter the same in sintering.
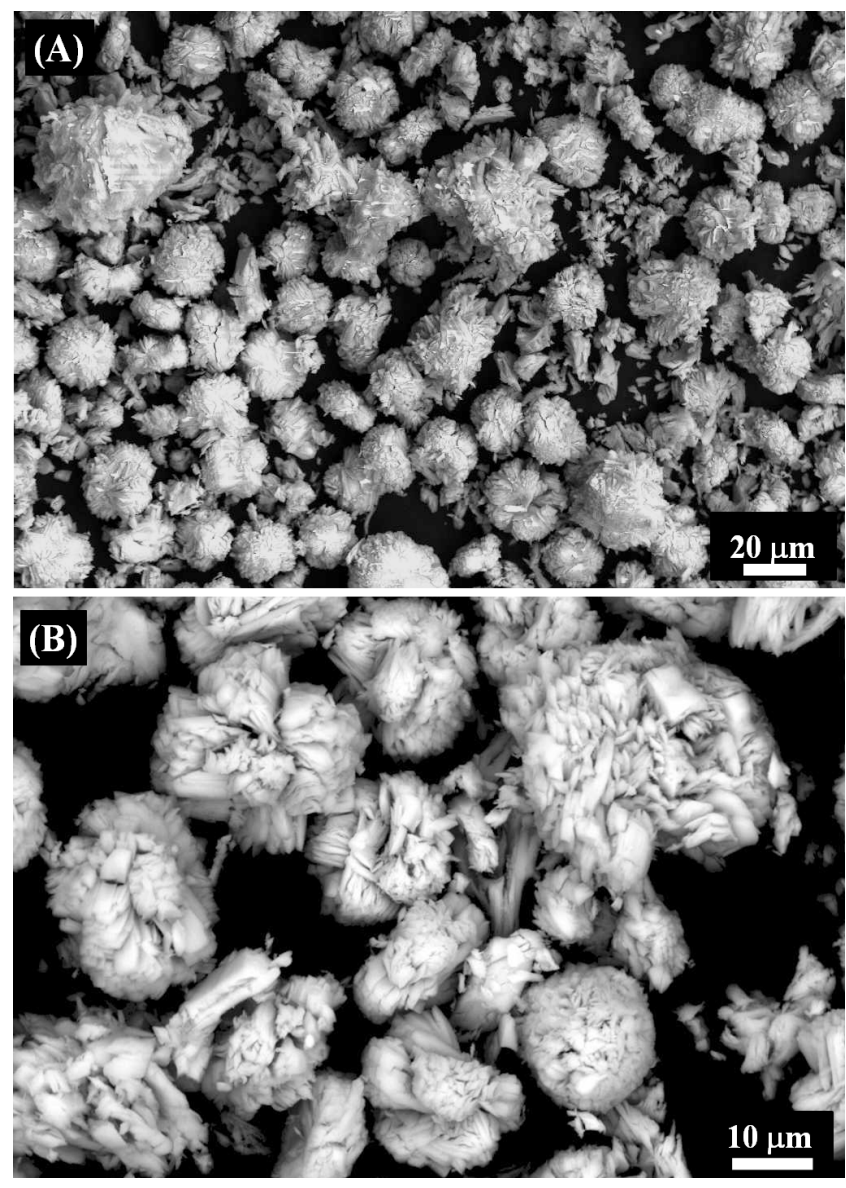

Figure 5: SEM micrographs of $\mathrm{RE}_{2} \mathrm{O}_{3}$ particles showing evenlyrounded clusters.

[Figura 5: Micrografias obtidas por microscopia eletrônica de varredura das partículas de $\mathrm{RE}_{2} \mathrm{O}_{3}$ mostrando aglomerados uniformemente arredondados.]

\section{CONCLUSIONS}

The study of optimization of the mixed rare earth oxide $\left(\mathrm{RE}_{2} \mathrm{O}_{3}\right)$ by the process of hydrometallurgy from the use of the full $2^{3}$ factorial and Plackett-Burman (PBD) designs, and also the study of the effects of these factors on alkaline fusion steps, oxalic acid leaching and precipitation, had the following results in the step of alkaline fusion using full $2^{3}$ design, average yield of $67.27 \%$ increased to $96.20 \%$ when 
all variables simultaneously passed the level -1 to level +1 . Analyzing Student t-test, the main effects of factors A (melting temperature), $\mathrm{B}$ (ratio of $\mathrm{NaOH} /$ xenotime), $\mathrm{C}$ (time), and the effect of interaction between $\mathrm{A}$ and $\mathrm{B}$ were statistically significant at a $95 \%$ level of confidence. The well-adjusted results in the graph of the predicted values versus experimental values gave an empirical model of first order with coefficient of determination $\mathrm{R}^{2}=0.92$, and with the analysis of the $\mathrm{F}$ test a $\mathrm{F}_{\text {calculated }}$ value well above the $\mathrm{F}_{\text {tabulated }}$, for a $95 \%$ level of confidence, was obtained. The RSM was obtained satisfactorily and correlated positively with the yield response variable so that, insofar as the manipulated variables increased, the reaction yield also increased. In the oxalic acid leaching and precipitation using the PBD, the analysis of the Pareto chart and desirability function showed that among the seven factors evaluated, the excess $\mathrm{HNO}_{3}$ (EA) showed the greatest importance in the process followed by temperature (TL) with significant positive correlations with the yield of the acid leaching step. Considering the attainment of oxalic precipitation solution from the acid leaching step with four of the seven most significant factors according to the PBD design, the concentration of precipitant solution used for conversion of oxalates in rare earth oxides was $80 \mathrm{~g} / \mathrm{mL}$, thus obtaining a satisfactory yield of $98.25 \%$. This resulted in a material with adequate characteristics determined by chemical analysis, X-ray diffraction, scanning electronic microscopy and specific surface area, and indicated that the final cost production of $\mathrm{RE}_{2} \mathrm{O}_{3}$ can correspond to $80 \%$ reduction compared with commercial $\mathrm{Y}_{2} \mathrm{O}_{3}$.

\section{ACKNOWLEDGMENTS}

The authors thank the financial support of the Brazilian research funding institutions: CAPES, $\mathrm{CNPq}$ and FAPESP-00/08832-5.

\section{REFERENCES}

[1] K.M. Franken, Sci. Technol. 30, 7 (1995) 1941.

[2] Y. Jiang, A. Shibayama, K. Liu, T. Fujita, Hydrometallurgy $76(2005) 1$.

[3] J.P. Barbosa, F.E. Lapido Loureiro, in: Rare earth minerals: chemistry, origin and ore deposits, Natural History Museum, London (1993) 7.

[4] R. Dehghan, M. Noaparast, M. Kolahdoozan, S.M. Mousavi, Int. J. Miner. Process. 89 (2008) 9.
[5] C.M. Moore, In: "Mineral facts and problems", U.S. Bureau of Mines, USA (1981) 739.

[6] C.K. Gupta, N. Krishnamurthy, Extractive metallurgy of rare earths, CRC Press, Boca Raton (2004).

[7] S. Radhika, B.N. Kumar, M.L. Kantam, B.R. Reddy, Hydrometallurgy 110, 1-4 (2011) 50.

[8] L.A. Boatner, Rev. Mineral Geochem. 48, 1 (2002) 87.

[9] G.A. Moldoveanu, V.G. Papangelakis, Hydrometallurgy 117-118 (2012) 71.

[10] P. Alex, A.K. Suri, C.K. Gupta, Hydrometallurgy 50, 3 (1998) 331.

[11] R.C. Vickery, The chemistry of yttrium and scandium, Pergamon Press, New York (1960).

[12] P. Kikot, M. Viera, C. Mignone, E. Donati, Hydrometallurgy 104 (2010) 494.

[13] K. Wang, J. Li, R.G. McDonald, R.E. Browner, Hydrometallurgy 109 (2011) 40.

[14] A. Shemi, S. Ndlovu, V. Sibanda, L.D. Van Dyk, Int. J. Miner. Process. 127 (2014) 10.

[15] D.C. Montgomery, Design and analysis of experiments, Wiley, New York (2001).

[16] P. Wang, Z. Wang, Z. Wu, Chem. Eng. J. 193-194 (2012) 50.

[17] A. Tuncuk, S. Ciftlik, A. Akcil, Hydrometallurgy 134135 (2013) 80.

[18] A. Vatanara,A.N. Rouholamini, K. Gilani, R. Asgharian, M. Darabi, M. Rafiee-Tehrani, J. Supercrit. Fluid 40 (2007) 111.

[19] Z. Ekinci, E. Şayan, A.V. Beşe, O.N. Ata, Int. J. Miner. Process. 82 (2007) 187.

[20] R.L. Mason, R.F. Gunst, J.L. Hess, Statistical design and analysis of experiments, with aplications to engineering and science, John Wiley \& Sons, New Jersey (2003).

[21] R. Chi, Z. Xu, Metall. Mater. Trans. B 30 (1999) 189.

[22] J. Baltazar-Rodrigues, P. Rodrigues Jr, G.K. da Cruz, M.H. Lente, J.A. Eiras, Mater. Res. 17, 1 (2014) 1.

[23] X. Li, T. Liu, Q. Lin, R. Cao, Cryst. Growth Des. 10, 2 (2010) 608.

[24] L. Muresan, E.-J. Popovici, R. Grecu, L.B. Tudoran, J. Alloy Compd. 471, 1-2 (2009) 421.

[25] H.-J. Förster, Am. Mineral. 83 (1998) 1302.

[26] R. Chi, Z. Xu, Metall. Mater. Trans. B 30 (1999) 189.

[27] M.S. Safarzadeh, M.S. Bafghi, D. Moradkhani, M.O. Ilkhchi, Miner. Eng. 20 (2007) 211.

[28] S.C. Chehreh, M. Rudolph, T. Leistner, J. Gutzmer, A. Urs Peuker, Int. J. Mining Sci. Technol. 25 (2015) 877.

(Rec. 16/11/2016, Rev. 24/01/2017, 04/04/2017, Ac. 12/06/2017) 